East African Medical Journal Vol. 80, No. 7 July 2003

CONTRACEPTIVE PRACTICE AMONG MARRIED MARKET MEN IN NIGERIA

E.O. Orji, FMCOG, FWACS, Senior Lecturer/Consultant Obstetrician and Gynaecologist. and U. Onwudiegwu, FWACS, Professor/Obstesterician and Gynaecologist, Department of Obstetrics, Gynaecology and Perinatology, College of Health Sciences, Obafemi Awololwo University, Ile-Ife, Nigeria

Request for reprints to: Dr. E.O. Orji, Department of Obstetrics, Gynaecology and Perinatology, College of Health Sciences, Obafemi Awolowo University, Ile-Ife, Nigeria

\title{
CONTRACEPTIVE PRACTICE AMONG MARRIED MARKET MEN IN NIGERIA
}

\author{
E.O. ORJI and U. ONWUDIEGWU
}

\begin{abstract}
Background: Until recently, family planning researchers and service providers had focused almost exclusively on women. Men are often seen as uncooperative and uninterested in family planning or reproductive health.

Objective: To investigate the contraceptive knowledge, attitude and practice among married market men.

Design: A cross-sectional survey.

Setting: llesa Main Market, Osun State, Nigeria.

Subjects: Four hundred and fifty married market men were interviewed between November 2000 and January 2001.

Main Outcome Measures: Level of awareness and utilisation, reasons for non-use, influence of socio-demographic variables.

Results: All the men were aware of family planning and $60.9 \%$ are currently using a form of contraception with their spouse. Reasons for non-contraceptive use by $39.1 \%$ of the respondents include: family size not yet complete, religious opposition, afraid of contraceptive failure, still searching for a male sex. Christianity and education were significantly associated with contraceptive use and knowledge $(p<0.05)$. Conclusion: Men favour contraceptive use in Nigeria. Involving men by family planning providers is a winning strategy with benefits to both men and women.
\end{abstract}

\section{INTRODUCTION}

Among the major Nigerian ethnic groups, men dominate familial and social relations including production and reproduction(1). It is generally believed that men are opposed to family planning(2-4). Untill recently, family planning researchers and service providers had focused almost exclusively on women. However, studies in the last decade suggest that men generally favoured family planning(5-7). Therefore, many providers and programme designers have concluded that neglecting men and their reproductive health is a losing strategy with adverse consequences for both men and women $(8,9)$. As a result, interest in and commitment to involve men in reproductive health has intensified in the last decade.

This study was designed to investigate the contraceptive knowledge, attitude and practice among Nigerian market men. Information obtained would hopefully assist in promoting wider contraceptive practice among African men.

\section{MATERIALS AND METHODS}

A cross-sectional survey of market men in Ilesa main market, llesa, Osun State was carried out by means of a pretested structured questionnaire administered by trained interviewers conversant with English Language and local dialect (Yoruba). The questionnaires were translated to Yoruba for non-English speaking men. The market consists of about 1,300 closed stalls and 900 open ones. The population comprises majority of women and a substantial amount of men; the exact population figure is unknown. A wide variety of goods are sold in the market. Information was obtained on the socio-demographic characteristics, their knowledge, attitudes and practice of family planning. The data were collated, coded and fed into IBM. compatible Personal Computer for analysis.

\section{RESULTS}

Sixty four (14.2\%) of the respondents had no formal education, $36 \%$ had primary education, $38.2 \%$ secondary education, while $11.6 \%$ had tertiary education. Four $(0.9 \%)$ respondents were traditionalists, while 41.3\% were Moslems while $57.8 \%$ were Christians. The predominant tribe was Yoruba (63.1\%), Ibo (26.7\%), Hausa $(8.9 \%)$ and other minor tribes $(1.3 \%)$. Ten $(2.3 \%)$ men had no child, $96(21.3 \%)$ had $1-2$ children, $144(32.0 \%)$ had 3-4 children and $200(44.4 \%)$ had five or more children. Most of them $(74.2 \%)$ had one wife, $23.6 \%$ had $2-3$ wives and $2.2 \%$ had four or more wives. Twelve $(2.7 \%)$ men earned less than US $\$ 100$ per month, $24(5.3 \%)$ earned US \$100-\$200 per month while $414(92 \%)$ earn >US \$200 per month.

All the respondents were aware of contraception but only $60.9 \%$ were practicing a form of contraception 
with the spouse (Table 1). The most commonly used method was the condom (46\%) followed by Depo provera injection $(27.0 \%)$, IUCD. (11\%), Oral contraceptive pills $(8.8 \%)$, bilateral tubal ligaton $(4.4 \%)$ and traditional methods $(2.8 \%)$. The reasons for nonuse of contraception among 176 men $(39.1 \%)$ include: family not yet complete $(26.1 \%)$, not interested $(21.6 \%)$, religious opposition $(20.5 \%)$, afraid of contraceptive failure $(17.0 \%)$, interference with sexual satisfaction
(Condom) (5.7\%), still searching for a male sex $(5.7 \%)$. The sources of contraceptive services included chemist/pharmacist shop (46.7\%), family planning clinics (46\%), friends $(7.3 \%)$. Those respondents with higher level of education had better contraceptive knowledge compared to those with no formal education $(\mathrm{p}=0.002)$ (Table 2). There was a statistical significant association between religion and attitude of respondents $(\mathrm{p}=0.001)($ Table 3$)$.

Table 1

Contraceptive practice among the respondents

\begin{tabular}{lcc}
\hline & No. & $\%$ \\
Variable & & 60.9 \\
\hline Currently Practicing Contraception with Spouse: & 274 & 39.1 \\
$\quad$ Yes & 176 & 46.0 \\
No & 126 & 27.0 \\
Method of Contraception in Use: & 74 & 11.0 \\
$\quad$ Male Condom & 30 & 8.8 \\
Injectable Contraception & 24 & 4.4 \\
Intrauterine Contraceptive Pills & 12 & 2.8 \\
Oral Contraceptive Pills & 8 & 26.1 \\
Bilateral Tubal Ligation (BTL) & & 21.6 \\
Traditional Method & 46 & 20.5 \\
Reasons for Non-use of Contraception (among 176 men): & 38 & 17.0 \\
Family not yet complete & 35 & 5.7 \\
Not interested & 30 & 5.7 \\
Religious Opposition & 10 & 7.3 \\
Afraid of Contraceptive Failure & 10 & 46.7 \\
Still Searferes with Sexual Satisfaction (Condom) & & 46.0 \\
Sources of Contraceptive Services among (274 Men): & 128 & 128 \\
Chemist/Pharmacists & 20 & \\
Family Planning Clinics & & \\
Friends & & \\
\hline
\end{tabular}

Table 2

Influence of education on respondents knowledge

\begin{tabular}{lcccc}
\hline & \multicolumn{5}{c}{ Knowledge } \\
\cline { 2 - 5 } Education & Fair & Good & Very Good & Total \\
\hline No formal education & 8 & 26 & 22 & 56 \\
Primary education & 4 & 66 & 92 & 162 \\
Secondary education & 4 & 38 & 130 & 162 \\
Tertiary education & 2 & 12 & 38 & 52 \\
\hline Total & 18 & 142 & 282 & 442 \\
\hline
\end{tabular}

Chi-Square $=20.825$

$\mathrm{DF}=6$

$\mathrm{P}=0.002$ (Significant) 
Table 3

Influence of religion on attitude

\begin{tabular}{lccccc}
\hline & \multicolumn{5}{c}{ Attitude } \\
\cline { 2 - 6 } Religion & Poor & Fair & Good & Very Good & Total \\
\hline Christianity & - & 28 & 36 & 194 & 258 \\
Islam & 2 & 20 & 66 & 94 & 182 \\
Traditional & - & - & 4 & 288 & 4 \\
\hline Total & 2 & 84 & 106 & 444 \\
\hline
\end{tabular}

Chi-Square $=23.453$

$\mathrm{DF}=6$

$\mathrm{P}=0.001$ (Significant)

Forty men $(8.9 \%)$ believed that decisions on family planning should be the responsibility of the wife only while $80(17.8 \%)$ felt that only the husband should take the decision. However, most men, 324 (72\%) felt it should be a joint decision. Three men gave no response. While $212(77.4 \%)$ were satisfied with their current method of contraceptives, $62(22.6 \%)$ were not satisfied. Majority of the men, 338 (75\%) would advise friends and relatives to use family planning while 112 (25\%) would not.

A significant number, $176(39.1 \%)$ preferred more boys than girls, $144(32 \%)$ would prefer any combination of sexes, 94 (20.9\%) preferred equal number of boys and girls while only $30(6.7 \%)$ preferred more girls. Four $(0.9 \%)$ preferred only boys and two $(0.4 \%)$ preferred only girls.

\section{DISCUSSION}

All the men in this study were aware of family planning and $60.9 \%$ of them were practicing it. While in agreement with the global acceptance rate of 60\%(10) this finding support the new survey findings which show that many men know and approve of family planning in marked contrast to the stereotype of men as uncooperative and uninterested in family planning or reproductive health(11-13).

Most of the respondents got information about family planning from the mass media and health workers who informed them via personal contacts. These may be for the relatively high level of contraceptive practice among them. Mass media can expose men audiences to messages that can influence their reproductive health knowledge, attitude and behaviour $(14,15)$.

The level of education of respondents was found to positively influence knowledge about family planning such that the higher the educational status the better the level of knowledge $(P=0.002)$. In almost all countries surveyed between 1987-1997, men with more schooling are more likely to approve of family planning. The influence of education is most striking in Cameroon, where only $20 \%$ of men with no education approve of family planning, but $75 \%$ of men with secondary or higher education approve(12).

A large proportion of respondents had good attitude towards family planning and about three quarters of them believed that family planning decisions should be jointly taken by both partners. This differs from the conclusion of other authors(16), who observed from a study carried out in Ghana that spousal influence of reproductive goals was an exclusive right exercised only by the husbands. Also, more than three fifths or respondents strongly agreed to the fact that males have a role in family planning in contrast to many reports that men are indifferent or even opposed to family planning $(12,17,18)$.

The Christian religion appeared to favour good attitudes to family planning in comparison with what was obtained from other religious sects represented in the study $(\mathrm{P}=0.001)$. In a related study in Jordan (an Islamic nation), while large percentage of Jordanian men believed that the spacing of births is sanctioned by Islam, many of them think that modern contraceptive methods are not compatible with Islam(19,20). Family planning is usually opposed by Islamic religions for pronatalist reasons or because it is generally considered alien to the culture(21). Omran(9) however emphasised the lack of prohibition of temporary family planning in the Islamic literature though most scholars are opposed to surgical contraception(22).

The study also revealed a strong preference for male child among the respondents with about two fifths of them desiring have either all boys or more boys than girls. The preference and attempt to have more sons than daughters is rooted tradition on the premise that the males would help in the farm, an insurance for old age, agents of continuity for the family name and some 
are necessary to fulfill the priestly duty of pouring libation, without which the ancestral spirit will begin to fade as they are forgotten(21). Furthermore, the characteristics dominance and patrilineal traditions support large family size and men's reproductive motivations to a large extent affects the reproductive behaviour of their wives.

More than two fifths of the respondents using contraception used the male condom while the remaining proportion used methods distributed over a wider range. This findings are in keeping with that of Chipfakacha (10) which showed that most African men associated family planning with condom use and not other contraceptives.

Incompleteness of the family size was the commonest reason given for non-practice of contraception at the time of study. This reflects ignorance of the temporary nature of some methods. Other reasons include fear of contraceptive failure, interference with sexual satisfaction and the search for a particular sex. While many men use contraception or support their partner's use of it, survey results suggest that most men need more family planning information, education and services(10-12).

In conclusion, this study has shown that Nigerian men practice family planning and encourage their spouses to do so. Most of them strongly believe that men have a role to play in family planning. Therefore reaching men by policy makers and service providers is a winning strategy with benefits for both men and women. Programmes can find new ways to encourage sexual responsibility, to foster men's support of their partners' contraceptive choices and to address the reproductive health care of couples

\section{REFERENCES}

1. Isiugo-Abanihe, U.C. Productive Motivation and Family Preference among Nigerian Men. Stud Fam. Plann. 1994: 25:140-161.

2. Bongaardsts, J. and Bruce, J. The Causes of Unmet need for Contraception and the Social Content of Services. New York, Population Council, 1994 (Working Paper Series No. 69), p56.

3. Robey, B. Ross, J. and Bhushan, L. Meeting unmet Need: New Strategies. Population Reports; Series J. No. 43. Baltimore, John Hopkins school of Public Health, Population Information Programme, Sept. 1996; 35.

4. Westoff, C. F. and Bankole, A. The time dynamics of unmet need. An example, from Morocco. Fam. Plann. Persp. 1998; 24: 12-24.

5. Ozvaris, S.B., Dogan, B. G. and Akin, K: Male involvement in family planning in Turkey. World Health Forum, 1998; 19:76-78.

6. Nwageni, E.A., Ankomah, A. and Powell, R.A. Attitudes of men towards family planning in Mbeya Region, Tanzania: A rural urban comparison of qualitative data. J. Biosoci. Sci. 1998; 30:381-392.

7. Eze, A.C., Seroussi, M. and Raggers, H: Men's Fertility, Contraceptive use and Reproductive Preferences. Calverton, Maryland, Macro lnternational, 1996: 1-45.

8. De Castro, M.P.P. and De Castro, B. M. Meeting Men's Reproductive Health Needs. Pro-Pater in Brazil in Salia, J. and Tahir, S. (eds.). Innovative approaches to Population Programmes Management: Reproductive Health, Vol. 3, Kuala Lumpar, Malysia. International Council on Management of Population Programmes, 1995: 11-22.

9. Schulte, M.M. and Sonestein, F. L. Men at family planning clinics. The new patients? Fam. Plann. Perspect. 1995: 27:212-225.

10. Chipfakacha, V.G. Attitudes of males on contraception: a KAPE survey. East Afr. Med. J. 1993; 70: 82-84.

11. Robey, B. and Drennan, M. Male participation in reproductive health. Network 1998: 18:11-15.

12. Ezeh, A.C., Seroussi, M. and Raggers, H. Men's Fertility, Contraceptive use and Reproductive Preferences. Calverton, Maryland, Macro International, March 1996 (D.H.S. Comparative Studies No. 18), p45.

13. Roudi, F. and Ashford, L. Men and Family Planning in Africa (Chartbook of DHS Data). Washington, D.C. Population Reference Bureau, July 1996.

14. Piotrow, P.T. and Duverhe, E. Communication makes a Difference! Informatie en Internationale Ont wikkeling 1996; 8:2-5.

15. Witwer, M. In Sub-Saharan Africa, levels of knowledge and use of contraceptives are linked to media exposure. Int. Fam. Plann. Perpect. 1997; 23:183-184.

16. Ezeh, A.C. The Influence of spouses over each other's contraceptive attitudes in Ghana. Stud. Fam. Plann. 1993; 24:163-174.

17. Boulos, M.L., Boulos, R. and Nichols, D.J. Perceptions and practices relating to condom use among urban men in Haiti. Stud. Fam. Plann. 1991; 22:318-325.

18. Mbizvo, M.T. and Bassett, M.T. Reproductive Health and AIDS prevention in sub-saharan Africa. The case for increased male participation. Health Policy and Planning, 1996; 2:84-92.

19. Underwood, C. Family Planning Knowledge, Attitudes and Practices in Jordan, Amman, Jordan. Jordan National Population Commission. General Secretariat, Oct, 1997; 61.

20. Farsoun, M., Khoury, N. and Underwood, L. In their own Words: A Qualitative Study of Family Planning in Jordan. Laltimore, Johns Hopkins School of Public Health Centre for Communication Programmes, Oct. 1996 (Field Report No. 6), 44p.

21. Ladipo, O.A. Socio-Cultural Barrier to contraception. Trop. J. Obstet. Gynae. 1996, 13:1-6.

22. Omran, A.R. Family Planning in the Legacy of Islam, London and New York; Routledge 1992: 1-8. 